\title{
Systems for the sustainable management of agricultural wastewaters
}

\author{
S. Barrington, I. Ali, S. Morin \& J. Whalen \\ Faculty of Agricultural and Environmental Sciences, \\ Macdonald Campus of McGill University, Canada
}

\begin{abstract}
Agricultural enterprises produce wastewaters in large quantities and from multiple sources. These wastewaters offer relatively low levels of nutrients and conventional land spreading equipment cannot apply these at a sustainable rate of $1000 \mathrm{~m}^{3} /$ ha. Two new application technologies were developed to better use the nutrients of these wastewaters in a sustainable fashion, while also using the water applied to the crop and reducing the application costs: a modified surfaced irrigation method and a modified seepage field associated with an organic matter trap and septic tank. The project tested the performance of both systems to obtain the best management practices. The modified surface irrigation system performed with minimal environmental impact when using a plot larger than that required for infiltration and applying the wastewater on dry soils using recommended irrigation rates. The adapted surface irrigation technique reduced the land spreading costs from $\$ 3.50$ to $\$ 1.00 \mathrm{Can}^{-3}$. The modified seepage field coupled with a septic tank worked well for the disposal of milk house wastewaters when managing the sediments and milk fat. The modified seepage field had limited impact on groundwater quality, but provided crop nutrients and reduced the investment cost of a treatment system for milk house wastewaters $\$ 15000$ to $\$ 6000 \mathrm{Ca}$., for a 60 cows dairy herd.
\end{abstract}

Keywords: agricultural wastewater, sustainable and economical treatment.

\section{Introduction}

Agricultural enterprises produce large volumes of wastewaters which are generally costly to handle because of their low nutrient content [1]. These wastewaters consist mainly of manure seepage produced from the decomposition 
of manure, from precipitations drained from solid manure piles stored outside, and from wash waters produced when cleaning facilities such as milking equipment and stalls. The operations producing the most wastewaters are dairy herds handling their manures as solids, and located in regions where precipitations exceed evaporation. In the United States and Canada, dairy operations with as many as 200 cows still handle their manures as solids and produce on an annual basis over $2000 \mathrm{~m}^{3}$ of wastewaters [2]. While costing over $\$ 7000 \mathrm{Ca}$. to spread on land, these wastewaters only offer only $\$ 500$ in crop nutrient value. Limited to an application rate of $100 \mathrm{~m}^{3} \mathrm{ha}^{-1}$, conventional manure spreading equipment is not designed to land spread wastewaters with such a low nutrient content because rates as high as $1000 \mathrm{~m}^{3} \mathrm{ha}^{-1}$ are required to supply the full crop nutrient requirements [3, 4].

The following are the requirements for the development of more efficient and sustainable systems to land apply such wastewaters: no nutrient accumulation within the recycling system on an annual basis; the valorisation of all components of the wastewater, including the water, and; the affordability of the technique for the continued viability of the farm operation. Nutrient accumulation can be avoided by applying rates equivalent to crop uptake. Cost affordability of the technique is ensured by developing a technique better adapted to land application. The development of the following two techniques was achieved to respect the definition of sustainable wastewater management. The objective of this paper was to describe these techniques and recommend best management practices for minimal environmental impact.

\section{Modified surface irrigation system}

A surface irrigation technique was developed to more effectively land spread large volumes of wastewater and to meet crop requirements, while still reducing the cost of handling such wastewater (Figure 1). The proposed concept consisted in laying a gated irrigation pipe on the ground, where the soil surface consistently sloped downwards, even at a low rate of $0.1 \%$. After being released by the gated pipe, the wastewater could run down the slope and cover the plot surface while infiltrating the soil. Wastewaters can be fed into this irrigation pipe by means of a flexible non perforated hose and an irrigation pump with a capacity of 3 to $10 \mathrm{~m}^{3} \mathrm{~min}^{-1}$. By collecting manure seepage and milk house wastewaters in a reservoir separate from that of the manure, large clumps of solids are avoided along with the risks of clogging the irrigation system. The nutrient content of the wastewater dictates the area of crop to be irrigated for a complete nutrient uptake, and this area in turn establishes the infiltration capacity and the pumping rate ensuring that the wastewaters will cover the entire plot area. A safety factor of 1.25 should be applied to increase the plot runoff length and prevent wastewater pounding at the foot of the slope.

\subsection{Environmental impact evaluation}

Once the equipment was found functional, the project consisted in testing its impact on groundwater quality using a control and irrigated silty soil plot each 
measuring 0.5 ha on the first dairy farm and 0.3 ha on the second farms with respective herds of 44 and 24 cows. All plots were drained using a subsurface system because ground wastewater losses could be measured at the outlet of this system during irrigation sessions. The project consisted in sampling and analyzing the wastewaters found in the storage tank of several farms located in the region South West of Montreal, Canada (table 1). With these results, the amount of wastewater required to supply nutrients to a corn silage crop was calculated (table 2).

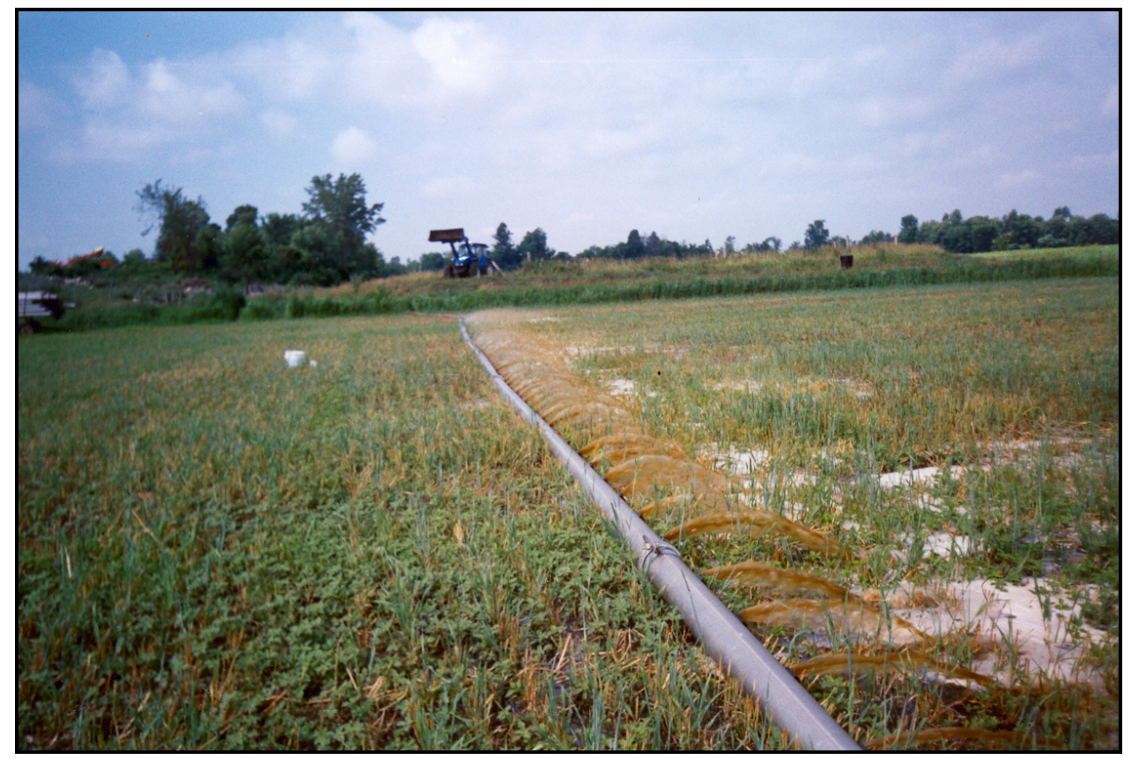

Figure 1: The modified surface irrigation system consists of a farm tractor and pump in the background, at the wastewater storage pit. A flexible hose brings the wastewater to the gated irrigation pipe for its release at the soil surface where it flows over the soil surface and spreads by itself.

While respecting the rate associated with the most environmentally limiting nutrient (phosphorous), the test then consisted in applying various rates of wastewater, and measuring the losses at the subsurface drainage outlet (table 3). The water table height was monitored before and after each irrigation session, along with the surface soil moisture content, to be able to recommend best management practices. 
Table 1: $\quad$ Characteristics of experimental agricultural wastewaters $[2,3]$.

\begin{tabular}{llll}
\hline Element & \multicolumn{3}{c}{ Source } \\
\cline { 2 - 4 } & MH & \multicolumn{1}{c}{ MS } & \multicolumn{1}{c}{ MH \& MS } \\
\hline TS, \% & $0.25-0.30$ & $0.60-1.55$ & $0.25-1.50$ \\
$\mathrm{SS}, \%$ & $0.03-0.06$ & $0.60-1.28$ & $0.22-1.45$ \\
$\mathrm{DS}, \%$ & $0.22-0.27$ & $0.03-0.10$ & $0.03-0.25$ \\
$\mathrm{pH}$ & $5.5-7.0$ & $7.0-7.5$ & $6.0-7.5$ \\
$\mathrm{TKN}, \mathrm{mg} \mathrm{L}^{-1}$ & $40-100$ & $150-1000$ & $50-1100$ \\
$\mathrm{TP}, \mathrm{mg} \mathrm{L}^{-1}$ & $70-130$ & $12-50$ & $15-90$ \\
$\mathrm{TK}, \mathrm{mg} \mathrm{L}^{-1}$ & $150-300$ & $200-600$ & $200-1000$ \\
TC,CFU mL & 5000 & $20-2000$ & $50-3000$ \\
FC, CFU mL & 2000 & $20-100$ & $10-2000$ \\
FS, CFU mL & 3000 & $50-1800$ & $5-16000$ \\
n (farm sampled) & \multicolumn{2}{c}{2} & \multicolumn{2}{c}{3} \\
\hline
\end{tabular}

Note: CFU - colony forming unit; $\mathrm{MH}$ - milk house; MS - manure seepage.

Table 2: Crop nutrient requirements as compared to wastewater nutrient content.

\begin{tabular}{cccc}
\hline MS\& MH & \multicolumn{3}{c}{ Application to meet crop requirements $\left(\mathrm{m}^{3} \mathrm{ha}^{-1}\right)$} \\
\hline Year* & $\mathrm{N}$ & $\mathrm{P}_{2} \mathrm{O}_{5}$ & $\mathrm{~K}_{2} \mathrm{O}$ \\
2002 & 2780 & 1390 & 125 \\
2003 & 1040 & 1360 & 185 \\
2004 & 940 & 860 & 170 \\
$\mathrm{MS}$ & & & \\
Year* & $\mathrm{N}$ & $\mathrm{P}_{2} \mathrm{O}_{5}$ & $\mathrm{~K}_{2} 0$ \\
2002 & 870 & 1800 & 285 \\
2003 & 500 & 1000 & 160 \\
2004 & 170 & 660 & 120 \\
\hline Crop requirement* & 150 & 62 & 120 \\
\hline
\end{tabular}

Note: * corn silage nutrient uptake in $\mathrm{kg} \mathrm{ha}^{-1}$ for a yield of 30 tons ha ${ }^{-1}$ at $35 \%$ dry matter content.

*wastewater application rate based on observed nutrient load for three consecutive years, on two individual dairy farms.

\subsection{Results of the environmental impact evaluation}

Table 3 summarizes the wastewater losses obtained with the various application rates on the first farm with a herd of 44 cows. Those of the second farm were similar and are therefore not presented.

For both farms, losses of wastewater occurred when applying the wastewater at high rate (exceeding $500 \mathrm{~m}^{3} \mathrm{ha}^{-1}$ ), after a rainfall increasing the water table height above that of the subsurface drainage system. To avoid seepage losses, it was therefore recommended to apply the wastewater during dry spells when the water table was below the subsurface drainage system, and to respect irrigation application rates as recommended by Schwab et al. [5]. 
Table 3: $\quad$ Losses of wastewater by subsurface drainage system.

\begin{tabular}{|c|c|c|c|c|}
\hline $\begin{array}{l}\text { Irrigation } \\
\text { session }\end{array}$ & $\begin{array}{l}\text { Application } \\
\text { rate, } \mathrm{m}^{3} \mathrm{ha}^{-1}\end{array}$ & $\begin{array}{l}\text { Rainfall } \\
\mathrm{mm}^{*}\end{array}$ & GW depth, m & $\begin{array}{l}\text { Drainage } \\
\text { losses, } \mathrm{m}^{3}\end{array}$ \\
\hline $1^{\text {st }}$ & 450 & 0 & & \\
\hline $2^{\text {nd }}$ & 230 & 30 & & \\
\hline $3^{\text {rd }}$ & 630 & 20 & & 1.6 \\
\hline \multicolumn{5}{|l|}{ Year 2} \\
\hline \multirow[b]{2}{*}{$1^{\mathrm{st}}$} & \multirow[b]{2}{*}{538} & \multirow[b]{2}{*}{6} & $0 \mathrm{~h}->1.60$ & \\
\hline & & & $\begin{array}{l}3 \mathrm{~h}->1.60 \\
20 \mathrm{hr}-1.12\end{array}$ & \\
\hline \multirow{3}{*}{$2^{\text {nd }}$} & \multirow{3}{*}{552} & \multirow{3}{*}{12} & $0 \mathrm{~h}->1.60$ & \\
\hline & & & $5 h-0.80$ & \\
\hline & & & $0 \mathrm{hr}-1.37$ & \\
\hline \multirow{2}{*}{$3^{\text {rd }}$} & \multirow{2}{*}{682} & \multirow{2}{*}{100} & $4 \mathrm{hr}-0.31$ & \\
\hline & & & $\begin{array}{l}6 \mathrm{hr}-0.45 \\
72 \mathrm{hr}-1.1\end{array}$ & 4.0 \\
\hline
\end{tabular}

*rainfall within 2 days of irrigation session; GW - ground water table; GW depth was observed as of the start of the irrigation session; drainage losses as measured at the subsurface system outlet.

When applied under dry soil conditions, crop yield was increased by $20 \%$ and crop protein content was increased while its fibber content was decreased. A time study also conducted during the irrigation sessions indicated that the application procedure required only 2 to 3 hours as compared to 2 to 3 days with conventional equipment. The cost of land spreading the wastewaters was therefore reduced to $\$ 1.00$ as compared to $\$ 3.50 \mathrm{Can} \mathrm{m}^{-3}$, excluding the benefits of increasing crop yield and quality.

\section{Modified septic system for milk house wastewaters}

To develop a method of disposing of milk house wastewaters for dairy farms with at the very most 60 mature cows, a modified seepage system was also developed. For such farms, a conventional septic system is still the least expansive method of disposal for milk house wastewaters, but clogging problems often result and nutrients generally accumulate in the soil surrounding the seepage field. When using a conventional septic system, the heavy milk fat and sediment loads often exceed the septic tank digestion capacity and lead to the washing of organic material and their accumulation within the sewer pipes of the seepage field. The large volume of wastewater applied conventionally over a small surface area generally saturates the soil with wastewaters which in turn losses its permeability and accumulates nutrient often exceeding its adsorption capacity.

To solve these issues with a sustainable solution, a modified seepage system was designed (Figures 2 and 3): a trap was installed before the septic tank to capture sediments and milk fat and manually remove these on a regular basis; 
this trap was easier to clean than the septic tank itself, and reduced risks of loading the septic tank above its digestion capacity. The seepage field was designed on the premises that land was not a restraint on dairy farms, as compared to residential lots. Installed in a cropped field of sufficient size, the nutrients accumulating in the soil around the sewer pipes could be removed by the plants.

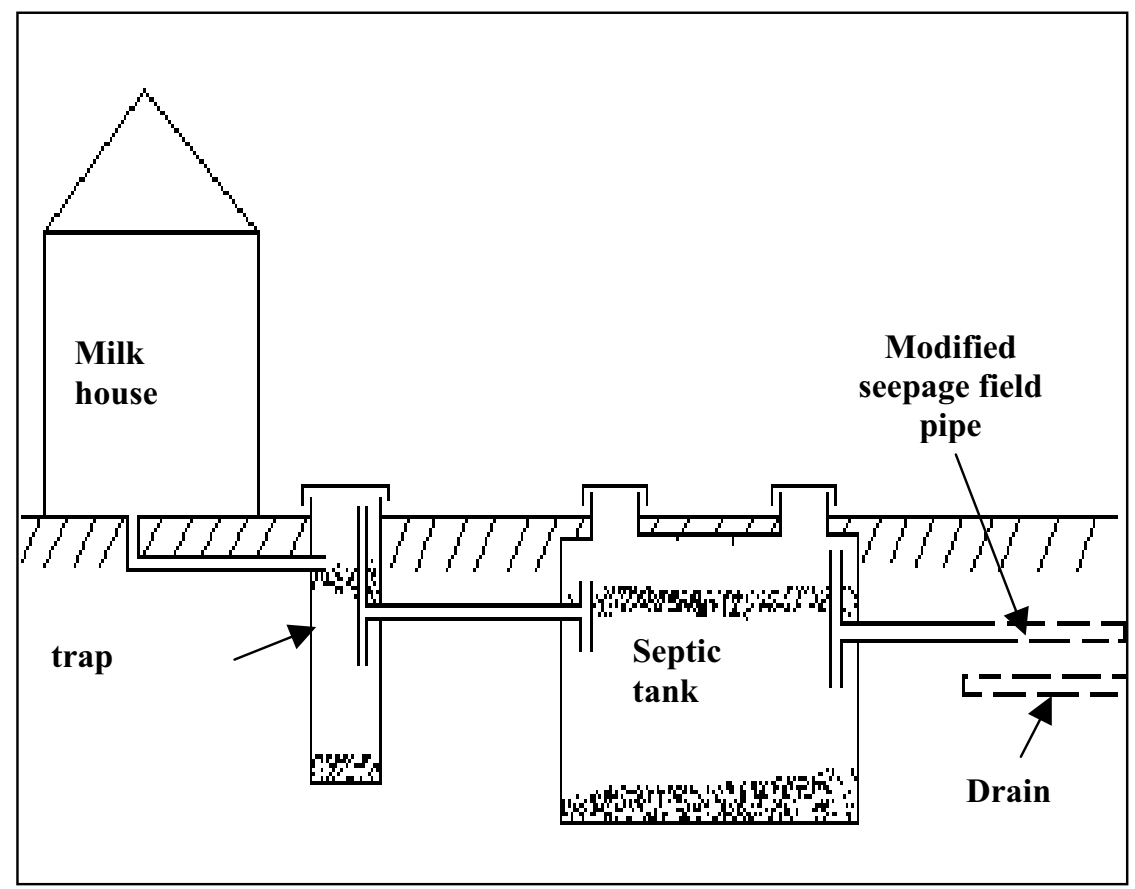

Figure 2: $\quad$ Modified septic system consisting of a grease and sediment trap installed before the septic tank, and a large seepage field of 0.5 ha with a drainage system to insure proper soil filtration.

The wastewaters produced by a herd of 50 dairy cows produced enough nutrients to supply 0.50 ha of cereals (Figure 3). Therefore, the sewer pipes of the seepage field measured $100 \mathrm{~m}$ in length and were spaced $15 \mathrm{~m}$ apart. The coverage of a large surface of cropped land reduced the risks of soil saturation both by water and nutrients. A filter envelop was installed on the sewer pipes to eliminate the need for a bed of crush stone. The sewer pipes were installed without a slope at a depth of 550 to $650 \mathrm{~mm}$, by allowing one or two $2.4 \mathrm{~m}$ sections to drop by 50 to $100 \mathrm{~cm}$. A standard agricultural drain (perforated and corrugated drainage tubing) was installed between each run of sewer pipe, but $150 \mathrm{~mm}$ lower, to maintain a water table level below that of the seepage field, and to force nutrients to filter into the ground, especially during the winter, in the 
absence of a crop. The milk house wastewaters applied on such a large surface do not contribute enough water to promote higher yields.

Because the nutrients supplied through the seepage field corresponded to that of the crop uptake, the system was designed to be sustainable and to prevent the accumulation of nutrients, especially phosphorous. This adaptation is a marked contrast when compared to conventional seepage fields, which are concentrated over a limited land surface and which build up nutrients over time, especially phosphorous. The wastewater nutrient load observed on two dairy farms with a herd of 40 and 50 cows, and over the span of three years is reported in table 1.

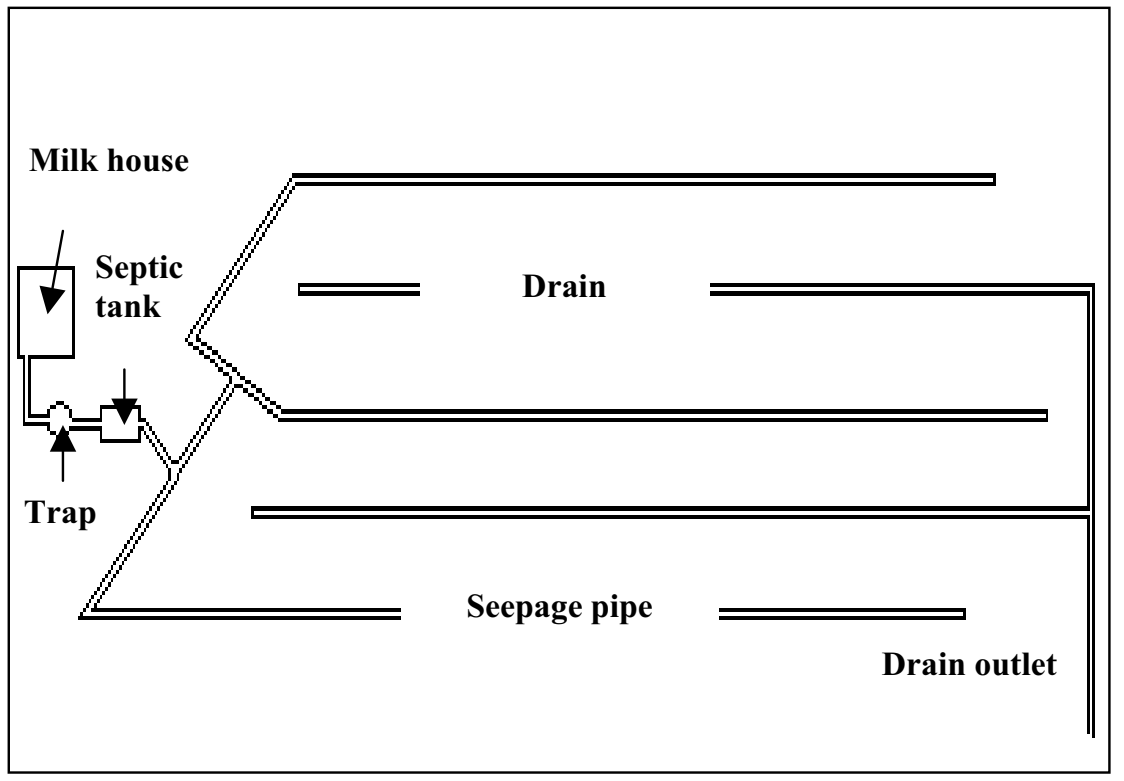

Figure 3: $\quad$ Plan view of one experimental modified septic system. The seepage pipes are spaced at $15 \mathrm{~m}$ and the drains are installed $150 \mathrm{~mm}$ below and half way between these seepage pipes, to control the level of the groundwater table.

\subsection{Environmental impact evaluation}

To evaluate the environmental impact of such a system, the amount of wastewater produced was measured by installing a water flow meter in the milk house of the two experimental dairy farms, located in the South West region of Montreal, Canada. After installing the system, the accumulation of milk fat and sediments was monitored in the trap and the quality of the waters drained by the drainage system installed between the seepage field pipes was monitored. The quality of drainage waters from the seepage field was compared to that of a control consisting of a nearby field also drained by a subsurface drainage system. 


\subsection{Results of the environmental impact evaluation}

Both farms were found to produce $13.5 \mathrm{~L} \mathrm{day}^{-1}$ of milk house wastewater cow ${ }^{-1}$ in the herd. The milk house wastewater characteristics were also found to be able to fertilize 1.0 ha of forage crop (100 dairy cows $)^{-1}$, if applied at a rate of $500 \mathrm{~m}^{3} \mathrm{ha}^{-1} \mathrm{yr}^{-1}$ for $50 \mathrm{~kg}$ of TP ha ${ }^{-1}$ (table 2).

On one experimental farm as opposed to the other, the trap accumulated as much as $250 \mathrm{~mm}$ of milk fat over an area of $1.13 \mathrm{~m}^{2}$, during the first year, because no water softener was used and the pipeline wasted milk was discharged into the septic system. Both farms accumulated sediments. Milk fat and sediment accumulation rates decreased with time over the span of three years of monitoring, likely because an appropriate microbial population was able to establish itself. Milk fat and sediments had to be removed from the trap every season to prevent their flow into the septic tank and sewer pipes of the seepage field.

The quality of the water drained from the seepage field was comparable to that drained from a control subsurface drain (Figure 4 and 5). No significant difference was observed when comparing the drainage waters of the seepage field and that of the control. Therefore the modified seepage field was observed to have a limited impact on the quality of ground waters.

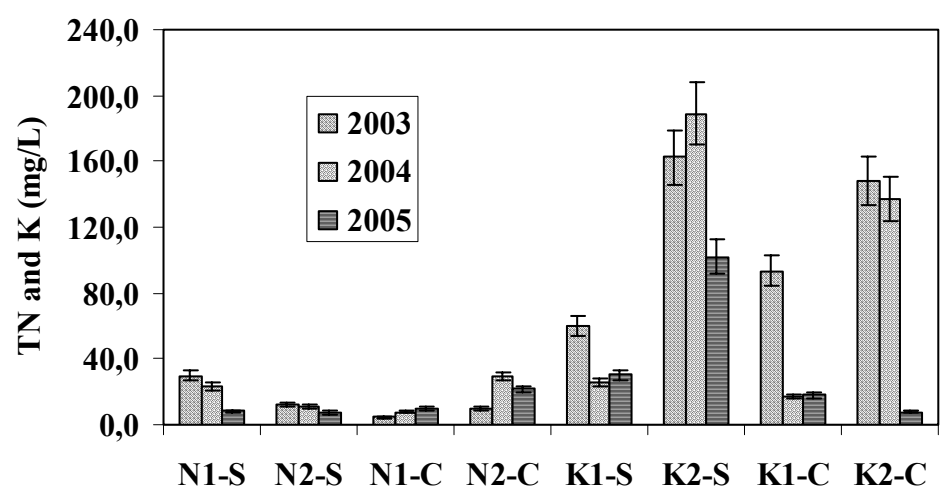

Figure 4: Drainage water quality collected from the modified seepage field and a control drain located in a cropped field receiving no wastewaters. $\mathrm{N}-$ Total nitrogen in $\mathrm{mg} \mathrm{L}-1$ and $\mathrm{K}-$ total potassium in $\mathrm{mg} \mathrm{L}-1$. The number besides the element symbol identifies the experimental farm.

At a total cost of $\$ 6000$ Can., the modified septic system was found to be quite affordable to build. The $350 \mathrm{~m}$ of sewer pipe lines and its subsurface drainage system, cost $\$ 3500$ to install while the trap cost $\$ 1000$ and the septic tank system cost another $\$ 1500 \mathrm{Can}$. 


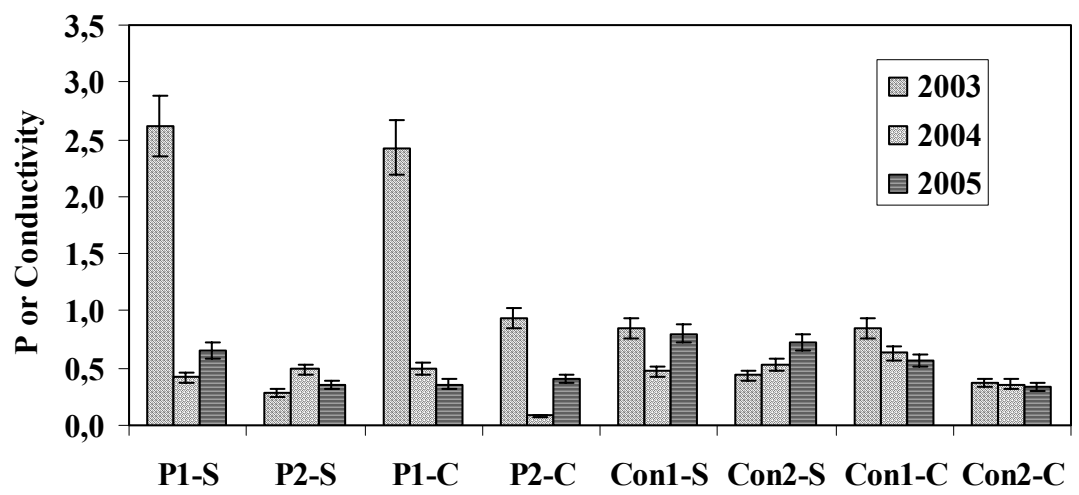

Figure 5: Drainage water quality collected from the modified seepage field and a control drain located in a cropped field receiving no wastewaters. $\mathrm{P}$ - Total phosphorous in $\mathrm{mg} \mathrm{L}-1$ and Conductivity in $\mathrm{mS} \mathrm{cm}-1$. The number besides the element symbol identifies the experimental farm.

Other techniques marketed for the treatment and disposal of milk house wastewaters are available at a cost of at least $\$ 15,000 \mathrm{Ca}$. and do not offer a system eliminating nutrient accumulation, especially phosphorous. The modified septic system is therefore a viable solution for the treatment of milk house wastewaters.

\section{Conclusions}

Two techniques were developed to dispose off agricultural wastewaters using sustainable concepts. These techniques were sustainable because they led to no nutrient accumulation, to the valorisation of all components of the wastewater including the water and to a lower management cost, thus improving the viability of the farm operation. The techniques consisted in a modified surface irrigation system and septic system, for the respective treatment of both manure and milk house wastewaters and only milk house wastewaters. The best management practices associated with both techniques consisted in applying the wastewaters on a surface large enough for their nutrients to be absorbed by the crop. Furthermore, no groundwater seepage losses were observed when the wastewaters were surface irrigated on a dry soil, at a rate respecting those recommended for irrigation. For the modified septic system, the milk fat and sediment trap had to be cleaned every season, to prevent the overloading of the septic tank and the clogging of the sewer pipes in the seepage field. 


\section{References}

[1] Loehr, R. 1984. Pollution control for agriculture. Academic Press Inc., New York, USA.

[2] Ribaudo, M.N., Gollehon, N, Aillery, M., Kaplan, J., Joahson, R., Agapoff, J., Christensen, V. 2003. Manure management for water quality: cost to animal feeding operations of applying manure nutrient to land. USDA Economic Research Service, Report AER-824, Washington, DC, USA.

[3] Ali, I., Morin, S. Barrington, S., Whalen, J., Martinez, J. 2006. Surface irrigation of dairy farm effluent. Part I. Nutrient and bacterial load. Journal of Biosystems Engineering, 95 (4), 547-556.

[4] Ali, I., Morin, S., Barrington, S., Whalen, J., Martinez, J. 2006. Surface irrigation of dairy farm effluent. Part II. System design and operation. Journal of Biosystems Engineering. 96 (1), 65-77.

[5] Schwab, G.O., Frevert, R.K., Edminster, T.W., and Barnes, K.K. 1986. Soil and water conservation engineering. John Wiley \& Sons, New York, USA. 